\title{
THE CONTROL OF THE ACID-BASE BALANCE DURING OPEN-HEART SURCERY*
}

\author{
WALTER ZingG, MD $†$
}

THE MAINTENANCE of the acid-base balance during extracorporeal circulation is of increasing importance as the scope of cardiac sungery is extended requirng prolonged periods of bypass A metabolic acidosis occurs frequently durng bypass and commonly during hypothermia Various methods have been described to deal with this problem It is the purpose of this paper to describe studies carried out in the years 1961-62 leading to a method which is now employed in all cases of extracorporeal circulation including those of several hours' duration. At the beginning the effects of hypothermia were studied both clinically and expermentally The principles evolved in this study were later applied to extracorporeal circulation with and without hypothermia

Many of the physiological disturbances caused by induced hypothermia have not been investigated adequately, although cooling procedures have been accepted as valuable adjuncts to cardiovascular surgery and to neurosurgery General hypothermia affects every organ and many of the biochemical components of the milieu inteneur The significance of these alterations is largely unknown, and often it is even unknown whether a certain change is beneficial or detrimental to the organism' under induced hypothermia Observations made in the laboratory are slowly improving our understanding, but the persons who are responsible for the clinical use of induced hypothermia still frequently find themselves in a dilemma In the planning of an operation and during the procedure they have to make certain decisions which are based on previous observations and expenence but which are not based on a thorough understanding or on sound scientific knowledge

This situation pertains to the acid-base balance Changes in temperature influence the buffer systems in varous ways and sometumes in opposite directions In the absence of hard and fast rules it awas decided to set up a working hypothesis based on theoretical considerations and on certain experimental observations The hypothesis consists of three parts

1 Estracorporeal circulation, especially durng hypothermia, is not as effective as the normal circulation Therefore, it is desirable to induce vasodilatation, partcularly in the brain since this organ is most likely to suffer damage by hypoxia associated with insufficient perfusion

2 Under hypothermia and after anoxic cardiac arrest, ventricular fibrillation may occur Therefore, towards the end of the cardiopulmonary bypass,

Presented, in part, at the Annual Meetung, The Royal College of Physicians and Surgeon of Canada, Edmonton, Alberta, January 17, 1963

From the Department of Surgery, The Unversity of Manitoba, Wunnpeg Children's Hospital, and Winnupeg General Hospital Work supported by the Manitoba Heart Foundation

PMedical College, Winnipeg 3, Manitoba 
conditions must be created which are favourable for defibrillation A temporary lowering of the $\mathrm{pH}$ is thought to be indicated at this time

3 The normal acid-base balance is meintained within a narrow range and deviations are not well tolerated Therelore, during cardiopulmonary bypass fluctuations of the $\mathrm{pH}$ should be avoided except the temporary' lowering menthoned above

The practical application includes the following components

1 Routne anaesthesia, but before bypass excessive hyperventilation is avoıded Anaesthetic agents having a vasodilating effect, such as halothane, are preferred during bypass

2 The $p \mathrm{CO}_{2}$ is kept within the normal range durnig bypass and it is raised slightly towards the end of bypass if ventricular fibrillation occurs

3 After bypass the $p \mathrm{CO}_{2}$ is reduced by controlled hyperventilation

4 Interference with the metabolic side of the acid-base balance is avoided Ammonium chloride, which is said to facilitate defibrillation, is never given Sodium bicarbonate is administered only if indicated

\section{Material aNd Mejhods}

Seventy-two consecutive patients undergoing open-heart surgery were studied, 23 of these under hypothermia $\left(25^{\circ} \mathrm{C}\right)$

In adults and older children an arterial needle was placed in the left radial artery and in these patients the acid-base balance was followed from the beginning of the anaesthesia through the operation and durng the first few hours in the recovery room During the extracorporeal bypass samples of blood were taken from the oxygenator In the smaller children, the arterial needle was not inserted Thus, only the samples taken from the oxygenator were avallable, supplemented by one or two blood samples taken by the surgeon from the aorta, shortly before and after bypass Heparnized syrmges were used throughout and suitable precautions were observed to avord admission of air into the syringe

The specimens were then analysed without delay on Astrup's apparatus ${ }^{1}$ with the microelectrode at a temperature of $37^{\circ} \mathrm{C}$ The $\mathrm{pH}$ was corrected for temperature using Rosenthal's factor ${ }^{2}$ and the $p \mathrm{CO}_{2}$ was corrected for temperature using Severinghaus' nomogram ${ }^{3}$

All operations were done by means of a Kay-Cross rotating disk oxygenator and roller pumps "The size of the oxygenator was chosen according to the weight of the patent $\mathbb{A}$ perfusion rate of $23-24 \mathrm{~L} / \mathrm{m}^{2} / \mathrm{min}$ was achieved in most patients In some the venous return was not adequate and the flow had to be decreased accordingly The roller pumps were calsbrated and the actual flow was checked by measurning the venous return at intervals during the procedure At a blood temperature of $25^{\circ} \mathrm{C}$ the peifusion rate was decreased to approximately 75 per cent of the predetermined flow Since at that temperature the total oxygen requirements are less than 50 per cent of normal, ${ }^{4}$ the high flow principle was maintained during hypothermia The temperatures of the patient and of the blood in the oxygenator and in the heat exchanger were recorded by means of 401 thermistors and telethermometers. $\uparrow$

Pemco Inc, Cleveland, Ohı

†Yellow Sprungs Instrument Co, Yellow Sprnngs, Ohı 


\section{RESULTS}

The presentation of biochemical data in a form which is accurate, simple, and clinically acceptable is not easy ${ }^{\circ}$ In this presentation the $\mathrm{pH} / p \mathrm{CO}_{2}$ diagram ${ }^{6}$ and the diagram introduced by Siggaard Anderson ${ }^{7}$ were used It is to be noted that in the latter diagram the $\mathrm{pH}$ is plotted on a linea: scale and the $p \mathrm{CO}_{2}$ on an inversed logarithmic scale in $\mathrm{mm} \mathbb{H}$ gxcesses of bale are expressed as positive

TABLE I

Cininical Data

\begin{tabular}{lcccc}
\hline \multicolumn{1}{c}{ Diagnosis } & Number & Age & Mortality \\
\hline Atrial septal defect & 21 & $4-53 \mathrm{yr}$ & 0 \\
Pulmonary stenosis & 6 & $5-44 \mathrm{yr}$ & 1 \\
Ventricular septal defect & 20 & $2-48 \mathrm{yr}$ & 3 \\
Congenital aortic stenosis & 11 & $3-16 \mathrm{yr}$ & 0 \\
Tetralogy of Fallot & 7 & $11-28 \mathrm{yr}$ & 2 \\
Acquired heart disease & 6 & $23-60 \mathrm{yr}$ & 5 \\
Pulmonary atresia & 1 & $8 \mathrm{jno}$ & 1 \\
Total & 72 & & 12 \\
\hline
\end{tabular}

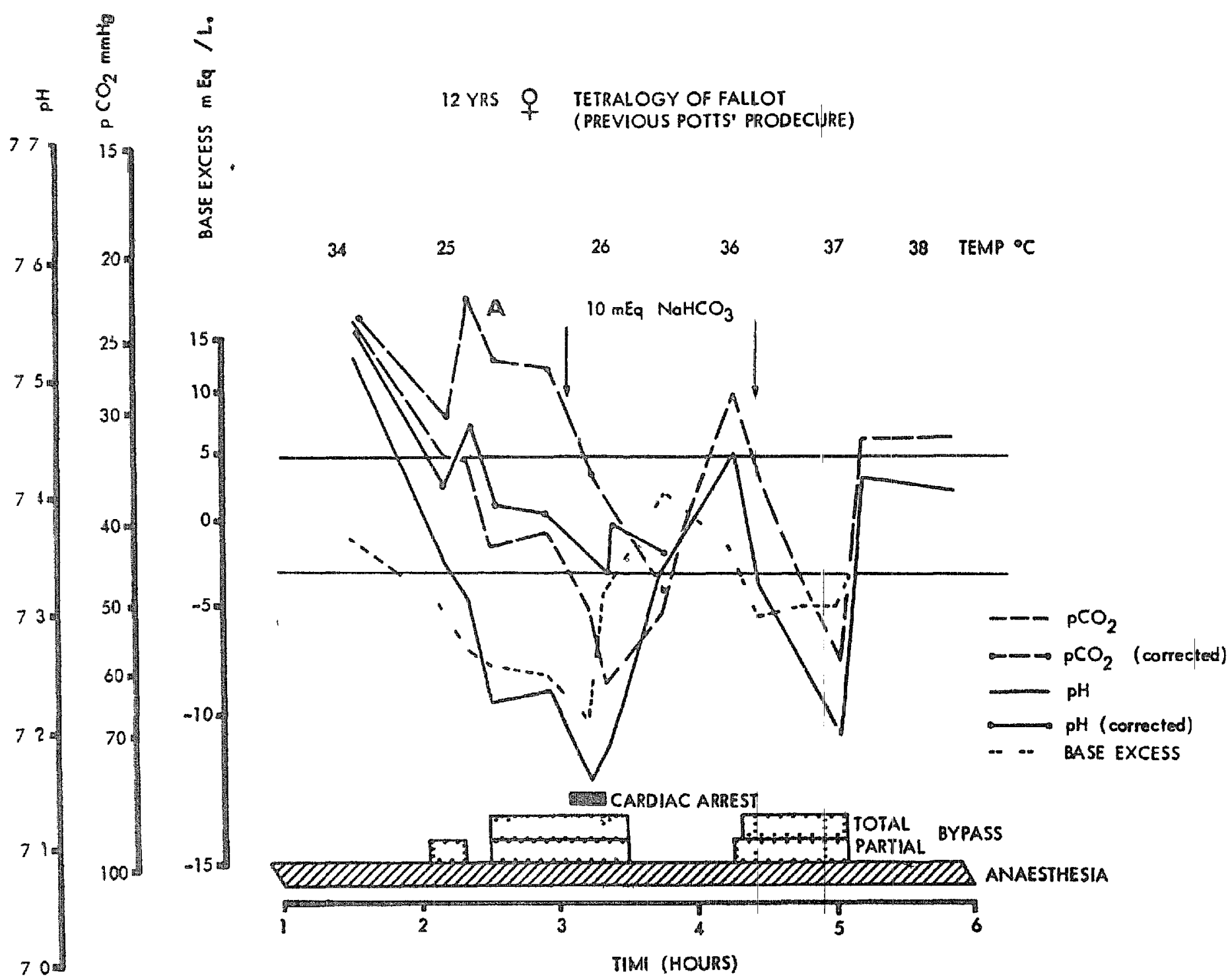

Frgune 1 Acid-base balance of a panent undergoing open-heart surgery for correctaon of a tetralogy with extracorporeal circulation and hypothermia After cooling to $25^{\circ}$ oesophageal temperature there was a 9 -minute period of circulatory arrest, followed by hypothermuc bypass with cardac arrest During a second period of normothermuc bypass the nght pulmonary outllow tuact was enlarged The corrected $\mathrm{pH}^{\mathrm{H}}$ and $p \mathrm{CO}_{3}$ values obtained during the hypothermia are moluded 
values and deficits as negative values in $\mathrm{mEq} / \mathrm{L}$ on a logarithmic scale with $\mathrm{a}$ sernum bicarbonate of $229 \mathrm{mEq} / \mathrm{L}$ as zero. The normal range is indicated by the two horizontal lines

The diagnosis and age of the patients are given in Table I

The biochemical data obtamed in a patient undergoing open-heart surgery for complete correction of a tetralogy of Fallot are summanzed in Figure 1 The patient, a girl, was born with a tetralogy of Fallot and had a Potts' procedure at the age of five years At age 12 definttive repaur of the lesions was performed During anaesthesia and before bypass, the changes associated with hyperventilaton were found As soon as the partial bypass and the hypothermia commenced there was an increase in $p \mathrm{CO}_{2}$, a drop in $\mathrm{pH}$, and an increase in the base deficit

At a temperature of $25^{\circ}$ complete circulatory arrest was instituted for a period of nine minutes, while the Potts' anastomosis was closed Then with the patient on complete cardiopulmonary bypass, the pulmonary stenosis and the ventricular septal defect were repaired, the latter under cardiac arrest produced by clamping the aorta at an oesophageal temperature of $25^{\circ}$ At point A ( Fig 1) the flow of gas into the oxygenator was decreased to less than one litre per minute because the $p \mathrm{CO}_{2}$ was found to be levelling off at too low a level Following the circulatory arrest a metabolic acidosis became evident and when a base deficit of 10 $\mathrm{mEq} / \mathrm{L}$ had been reached $10 \mathrm{mEq}$ of sodium bicarbonate was given intravenously The patient was then rewarmed After 20 minutes the temperature had returned to normal, the heart resumed a rhythmical acton spontaneously, and

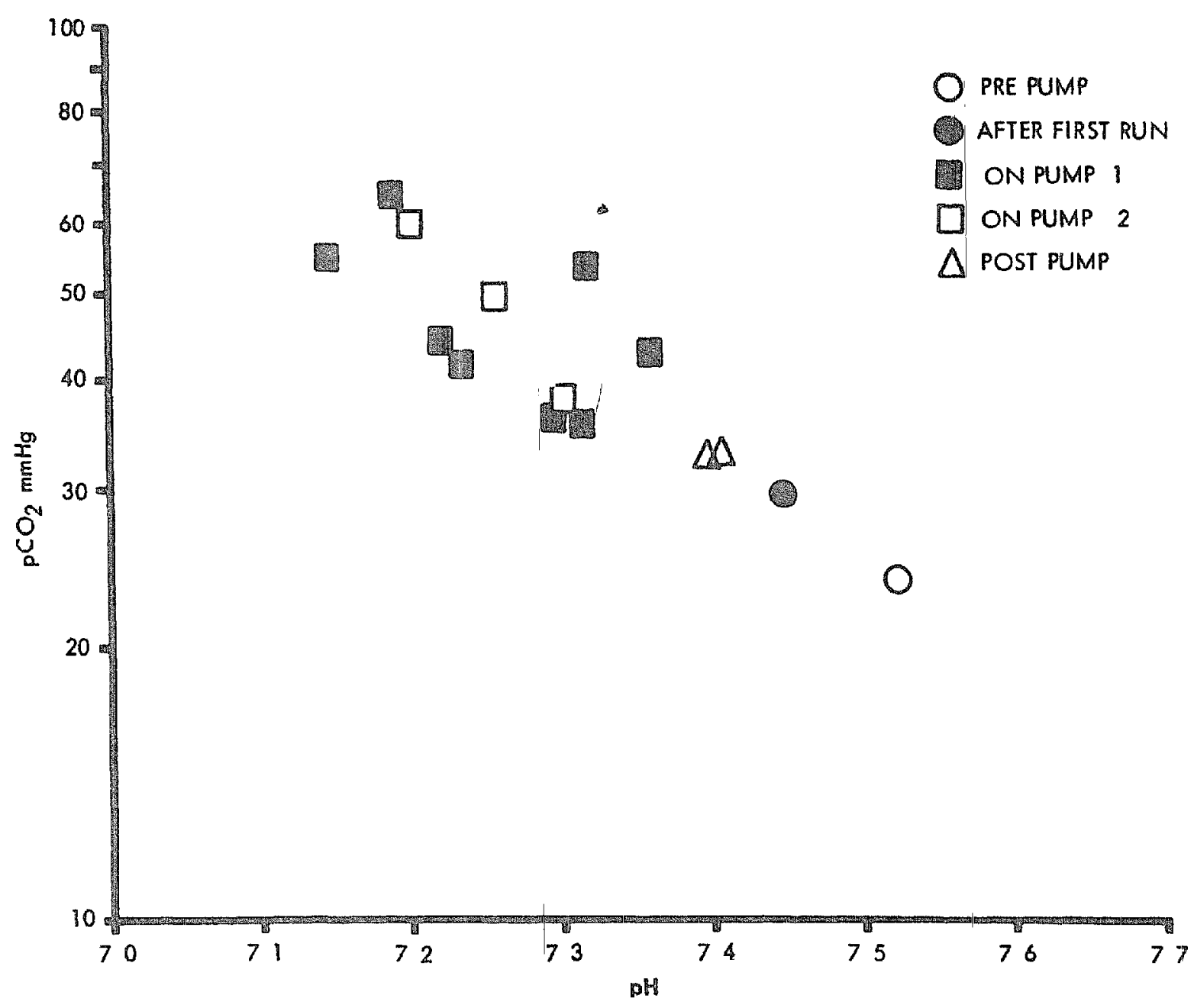

Figure 2 Same patient as in Figure 1 Uncorrected values plotted in $\mathrm{pH} / p \mathrm{CO}_{3}$ dragram 


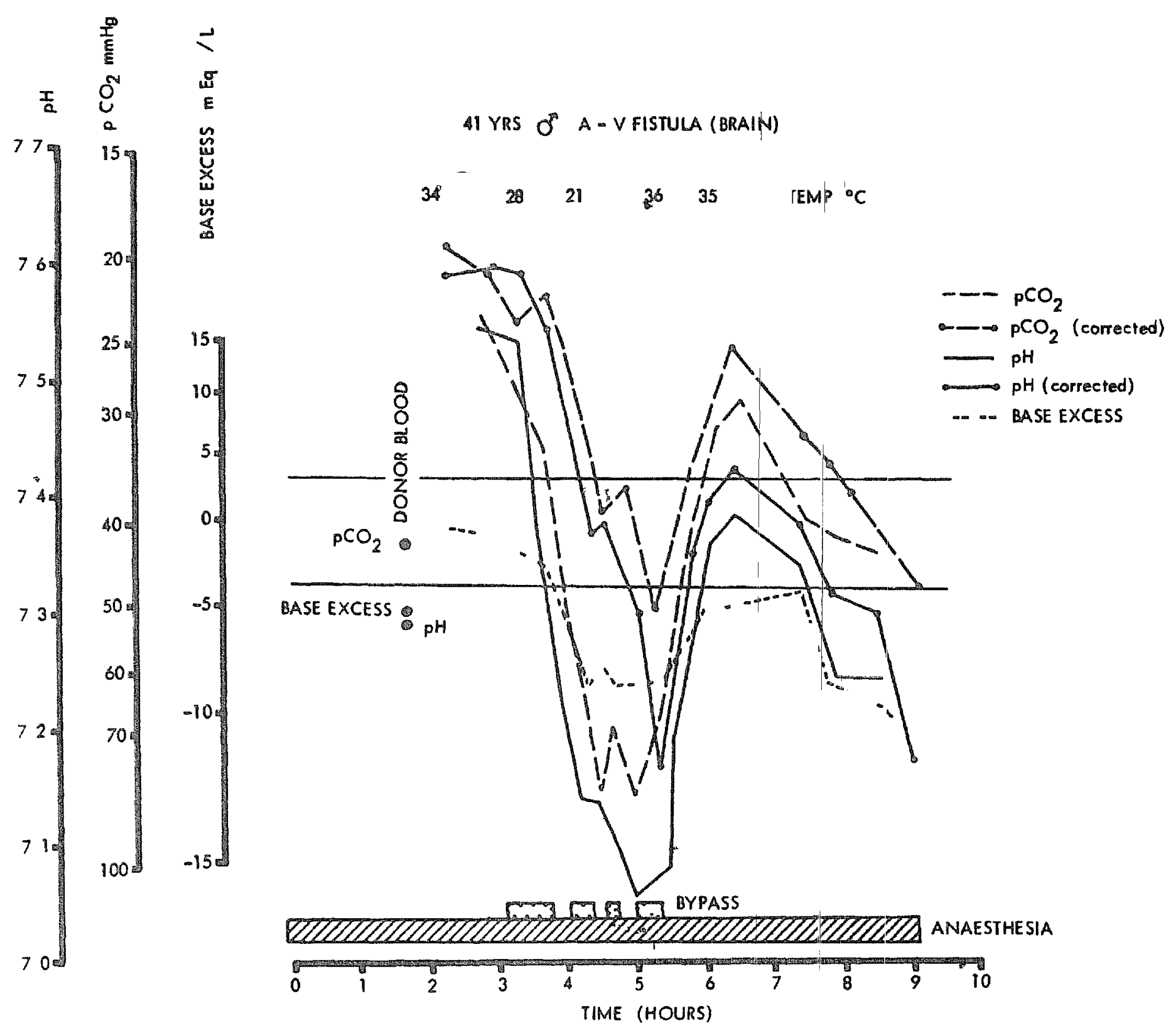

FIGURE 3 Acid-base balance of a patient undergoing neurosurgery with extracorporeal circulation and hypothermia The lowest oesophageal temperature was $21^{\circ}$ There were three penods of circulatory arrest totalling 36 minutes

the bypass was discontmued Pressures taken at that time revealed an excessive gradient between right ventricular and pulmonary artery pressures and it was decided to enlarge the right ventricular outflow tract by inserting a patch of pericardium Accordingly, cardiopulmonary bypass was. dgain instituted but without hypothermia The $p \mathrm{CO}_{2}$ increased again and since a further drop in base was anticipated, another $10 \mathrm{mEq}$ of sodium bicarbonate was given. After termination of the bypass the anaesthetist hyperventilated the patient and at the completion of the operation the $\mathrm{pH}$ and base were within the normal range, whereas the $p \mathrm{CO}_{2}$ was slightly lower than normal The $\mathrm{pH} / p \mathrm{CO}_{2}$ diagram is reproduced in Figure 2 The straight-line selationship is not as clear as in lesscomplicated cases, indicating some disturbance of the acid-base balance

The second case was operated upon shortly after the termination of the series and is presented as another example of a complicated procedure The patient, a 41-year-old white male, had undergone several previous operations attempting to improve an intracranial artenovenous fistula Finally it was decided to approach the lesion again under curculatory arrest and hypothermia, using the routne 
procedures of cardiopulmonary bypas $\$$ The crrculation was arrested three times, the total penod of arrest being 36 minutes The intra-operative acid-base status is presented in Figures 3 and 4 Several similarities with the last patient are apparent evidence of hyperventilation before bypass, then fall of $\mathrm{pH}$ and increase of $p \mathrm{CO}_{2}$ at the beginning of bypass and hypothermia At the time when the $p \mathrm{CO}_{2}$ levelled off, the flow of the gas mixture to the oxygenator was decreased to $11 / 2$ litres per minute and, following this, the $\mathrm{pCO}_{2}$ and the $\mathrm{pH}$ reached the desired levels The base deficit was not excessive, even after complete circulatory arrest, and no bircarbonate was given The straight-line relationship is manntained in the $\mathrm{pH} / p \mathrm{CO}_{2}$ diagram, confirming the absence of a marked metabolic acidosis

These two patients were chosen for detaled presentation because they illustrate the changes produced in the acid-base balance In other patents the period of cardiopulmonary bypass was shorter and the increase in $p \mathrm{CO}_{2}$ and the fall in $\mathrm{pH}$ were less pronounced

Figure 5 is a composite graph of all the uncorrected data obtained The dots

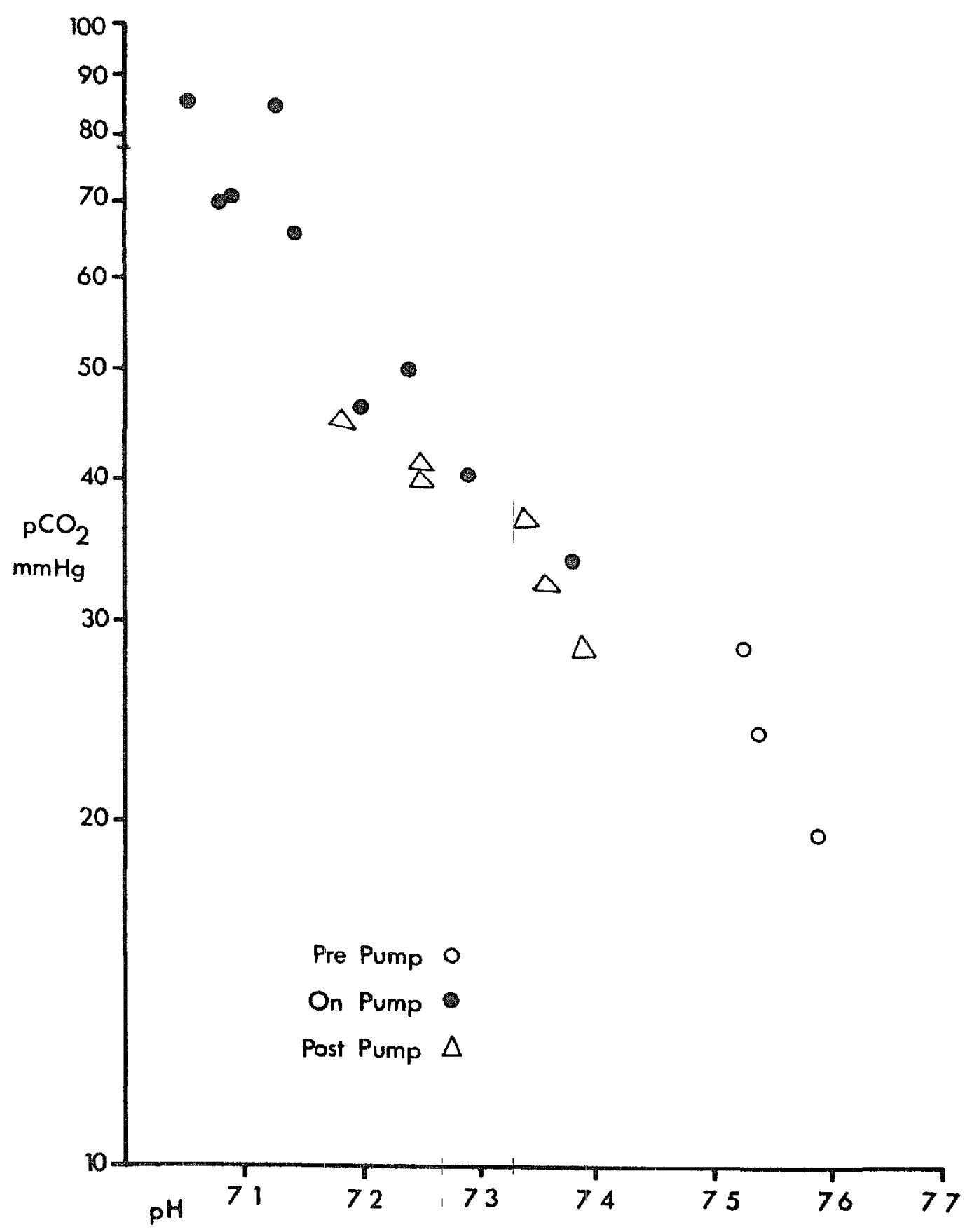

Figure 4 Same patient as in Figure 3 Uncorrected values plotted in $\mathrm{pH} / \mathrm{p} \mathrm{CO}_{2}$ dragram 


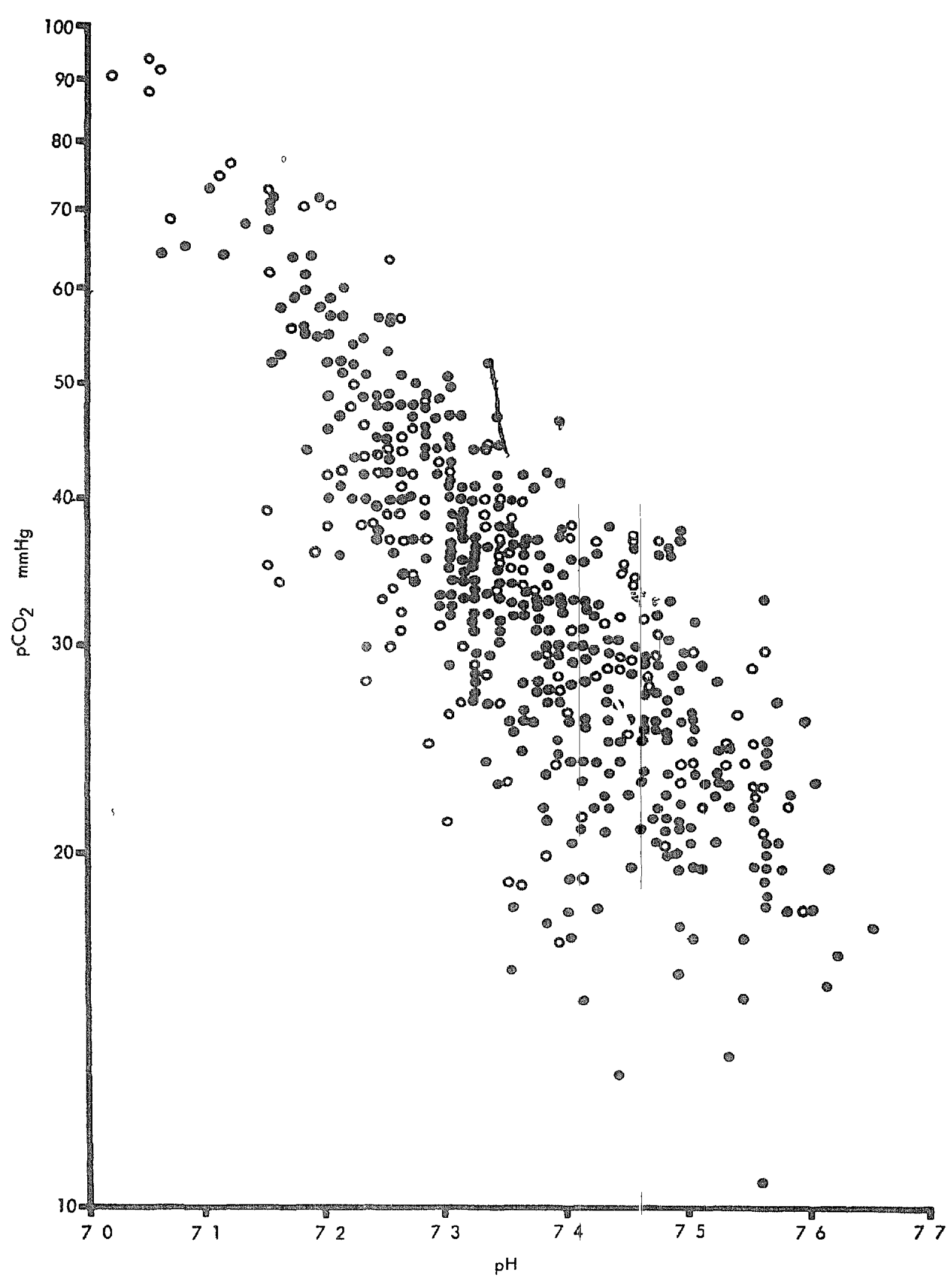

Figure 5 Composite $\mathrm{pH} / \mathrm{pCO}_{2}$ diagram incorporatung all data obtaned in the course of the study

are results obtanned in survivors, the circles are data obtaned in patients who died on the day of the operation It can be seen that the circles are scattered throughout the whole range but are relatively more frequent on the left side of the centre This illustrates the well-known fact that death following cardiopulmonary bypass is often associated with a metabolic acidosis In these patients 12 or more biochemical determinations weie performed, whereas in many short and successful cases only 3 or 4 were made This explams the large number of crrcles in the diagram The curcles in the left upper corner were obtained in a patient with acquired heart disease affecting both mitral and aortic valves The heart 
TABLE II

Means and Standard Deviations of $\mathrm{pH}, \mathrm{CO}_{2}$, AND Base Deficit in Donor Blood and during Carduopulmonary Bypass

(Figures in parentheses indicate the number of observations)

\begin{tabular}{|c|c|c|c|}
\hline & $\mathrm{pH}$ & $\mathrm{pCO}_{2}(\mathrm{~mm} \mathrm{Hg})$ & Base deficit $(\mathrm{mEq} / \mathrm{L})$ \\
\hline Donor blood & $729 \pm 005$ & $406 \pm 73(59)$ & $61 \pm 23$ \\
\hline Before anaesthesia & $741 \pm 003$ & $346 \pm 41$ (7) & $07 \pm 27$ \\
\hline One hour of anaesthesia & $748 \pm 007$ & $273 \pm 79(35)$ & $14 \pm 14$ \\
\hline Before bypass & $745 \pm 009(39)$ & $280 \pm 71(38)$ & $30 \pm 31$ \\
\hline \multicolumn{4}{|l|}{ End of bypass } \\
\hline Normothermia & $728 \pm 008(46)$ & $387 \pm 138(44)$ & $63 \pm 27$ \\
\hline Corrected & $732 \pm 008(27)$ & $379 \pm 100(27)$ & \\
\hline Hypothermua & $720 \pm 007 \quad(24)$ & $512 \pm 154$ & $752 \pm 26$ \\
\hline Corrected & $733 \pm 008(24)$ & $358 \pm 113(23)$ & \\
\hline End of operation & $736 \pm 011(35)$ & $310 \pm 136$ & $50 \pm 32^{*}(33)$ \\
\hline
\end{tabular}

Hypothermia cases $58 \pm 32$ (11) Normotherma cases $42 \pm 32$ (22)

resumed a regular ihythm after defibrillation but the patient died later, from haemorrhage In Figure 5, as well as in the Table II, all the data obtained during the course of this study are incorporated

Since the period of bypass was different in each patient it was difficult to obtain mean values of comparable states Ir Table II this was attempted by presentıng the mean obtamed at different stages (1) the donor blood, exposed to air, after it had been crrculated through the pump oxygenator, (2) arterial blood before anaesthesia, (3) arterial blood after induction of anaesthesia: (4) arterial blood immediately before bypass, (5) blood taken from the arternal end of the oxygenator towards the end of the bypass when the $\mathrm{pH}$ had reached its lowest value, divided into a hypothermic and a normothermic group (in many patients in the latter group the temperature had dropped $2-3^{\circ}$, in these and in all hypothermia cases the coriected values are also given ), (6) artenal blood at the end of the operation Values for 2, 3, and 6 could only be obtained in patients who had an indwelling arterial needle

The donor blood was one day old and slightly acidotic Immediately before bypass the effects of hyperventilation were evident, as shown by a high $\mathrm{pH}$, a low $p \mathrm{CO}_{2}$ and a small base deficit At the end of the operation there was evidence of a metabolic acidosis, more pronounced in the hypothermia cases than in those operated upon at normal body temperature The same data are represented graphically in $\mathbb{F}_{1}$ gure 6

\section{Discussiun}

Before discussing the working hypothesis and the results obtained, a short description of the method used for the intra-operative monitoring of the acidbase balance and an outline of the direct effect of hypothermia on the acid-base balance is presented

\section{The Intra-operatve Montonn of the Achd-Base Balance}

Additional interference with the acid-base balance demands additional safeguards The extent of the changes should be known at all tmes Contmuously 


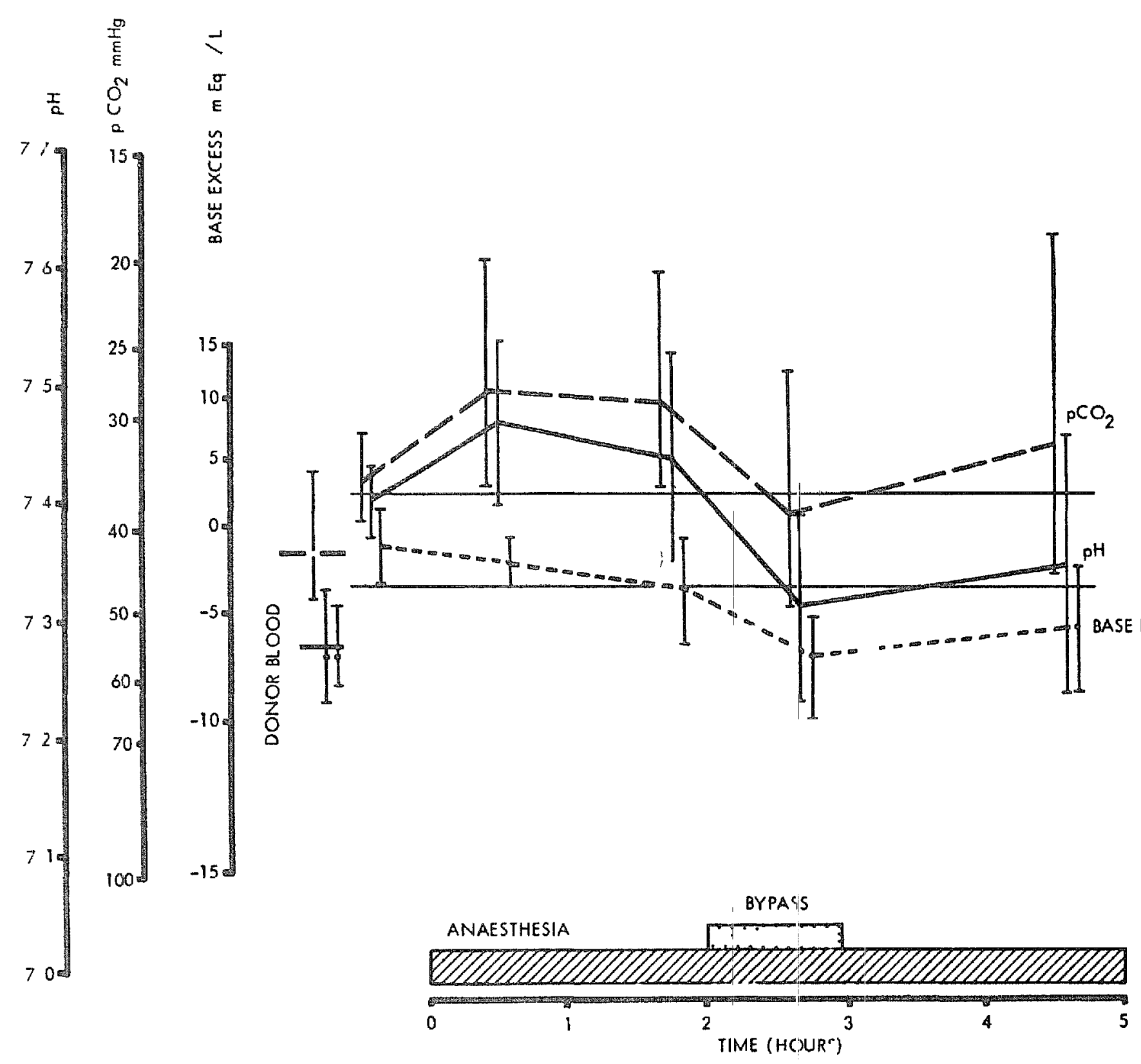

FIGURE 6 Means and standard deviations of the $\mathrm{pH}, p \mathrm{CO}_{2}$, and base excess in donor blood, in artenal blood before anaesthesia, after induction of anaesthesia, immediately before bypass, at the end of bypass, and at the end of the anaesthesia The tume relationships are approximations

recording instruments present a number of mherent difficulties and are not really required On the other hand, routine laboratory methods are too timeconsuming and do not lend themselves to rapid serial determinations Nomograms are of limited value, since the conditions for which these are calculated may not prevall during open-heart surgery

The ideal method, which is yet to be found, should be completely uninfluenced by changes other than those occurring in the acid-base status, and should also be rapid, easy to perform, and dependable The method and the apparatus recently described by Astrup and co-workers in Copenhagen fulfills many of these requirements ${ }^{8}$ It has been shown by Brewin et $a l^{6}$ that if the same blood sample is equilibrated at varying $\mathrm{CO}_{2}$ tensions, and then the $\mathrm{pH}$ values and the corresponding $p \mathrm{CO}_{2}$ values are plotted on semilogarithmic paper, the dots fall on a straight line The line is shifted to the left in acidosis and to the right in alkalosis Based on three $\mathrm{pH}$ determinations (the actual $\mathrm{pH}$ and two done after the blood sample has been equilibrated with known $\mathrm{CO}_{2}$ tensions), the actual $\mathrm{pH}$, the $p \mathrm{CO}_{2}$, and the base excess or deficit ${ }^{9}$ can be obtaned Since a sepaiate $\mathrm{pH} / \mathrm{pCO}_{2}$ lune is drawn for each sample, the results are independent of changes 
in the concentration of haemoglobin and plasma proteins. The $\mathrm{pH} / p \mathrm{CO}_{2}$ line is also sard to be independent of temperature ${ }^{6}$

Astrup's method has been designed for use at normothermia, and at the present time it is impossible to evaluate the method when the blood samples are taken at a lower temperature and warmed in the apparatus It is highly probable that the results obtained are not accurate even it correction factors are used However, experience has shown that, if a base deficit is found durng hypothermia, it is still present after the patient is rewarmed, and vice versa The same observation has been made in regard to the $p \mathrm{CO}_{2}$ changes and it is thought that the values obtamed, although perhaps maccurate, are still helpful in the assessment of the patients

\section{The Changes in the Acud-Base Balance Produced by Hypothermia}

It is not easy to give a résumé of the present state of knowledge, one of the main difficulties being the terminology The term $\mathrm{pH}$ was introduced in 1909 by Sorensen and defined as the negative logarnthm of the hydrogen ion concentration The hydrogen ion concentration itself is an unwieldy figure with several decimal points and Sorensen's concept simplified matters greatly The $\mathrm{pH}$ units are small figures and have been accepted uniformly, but it is conceivable that, in the light of newer knowledge, other units might be introduced ${ }^{10}$ Todlay according to both US and Britash standards, the pH values are purely arbitrary units, a certain value being assigned to a certain test solution Strictly speaking, then, it is not admissible to define the blood $\mathrm{pH}$ by means of the Henderson-Hasselbalch equation However, everybody is familiar with this equation, it is used in every treatise on the subject, and it serves well to explain some of the changes in the acid-base balance occurring when the temperature of the blood is changed With these limitations in mind the equation is used in the following discussion

\section{(a) Physicochemical Considerations}

In discussing the Henderson-Hasselbalch equation, $\mathbb{E}$ Nerl" stated that "other people (non-experts) are rushing in where angels fear to tread "Nevertheless, before attempting to describe the effect of ternperature changes on the acid-base balance, a partial review of the theoretical background appears mandatory Only a cursory description of the concepts which are needed to explain the temperature effects will be given

The situation is not as clear-cut as one might wish and it seems advisable to begin with a definition of the terms What do we mean by "acid" and "base"?

According to Clark' 12 the word "base" has at least five different meanings For Lavoisier a base was the principal ingredient of a compound The definitions of $G N$ Lewis are difficult to understand for those untrained in advanced chemistry In between, are the ionization theory and Bronsted's theory, which are thought to be most useful in the present context According to the former, a base is a substance that ionizes in water to give hydroxyl ions (an acid gives hydrogen 1ons) and the interactions between base and acid are associated with a combinaton of the hydroxyl and the hydrogen ion I $N$ Bronsted's concept is more general An acid is a proton donor, a base is a proton acceptor In the formula 
$H R \leftrightarrows R^{-}+H^{+}, H R$ is the acid and $R^{-}$its conjugate base. Both the acid and the base may be a cation, an anion, or an unchaiged molecule, but $\mathrm{R}^{-}$must always be more negative (or less positive) than HR ${ }^{13}$

In this paper, the term "base" will be used in this sense This is in contrast to Henderson's usage, which is often employed clinically (fixed bases, buffer base), meaning cations Thus protem is a base, since it combines with $\mathrm{H}^{+}$to form the conjugate acid $\mathrm{HP}$, and the bicarbonate ion $\left.\mathrm{HCO}_{3}\right\rceil$ is a base conjugate to carbonic acid $\mathrm{H}_{2} \mathrm{CO}_{3}{ }^{13}$

For the quantitative assessment of the acid-base balance (or of the degree of acidity or alkalinity) $\mathrm{pH}$ units are employed The exact measurement of the $\mathrm{pH}$ is difficult, requirng a hydrogen electrode Most laboratory $\mathrm{pH}$ meters make use of a glass electrode ${ }^{14}$ In these, the test solution is separated from a reference solution by a glass membrane An electrode is in contact with the reference solution, another electrode is in contact with the test solution by means of a liquid junction The interstices in the special glass used $t$ or the membrane permit the exchange of protons $\left(\mathbb{H}^{+}\right)$and accordingly a certaun electromotive force is produced across the glass, which after suitable amplification can be read off a meter The $\mathrm{pH}$ meter is first calibrated with a solution of known $\mathrm{pH}$ and then the test solution is introduced

The value obtanned with a pH meter does not conform strictly to Sorensen's definition of the $\mathrm{pH}$ The activity rather than the concentration of the hydrogen 1ons is measured ${ }^{15}$ and, when defined thermodynamically, the $\mathrm{pH}$ is an expression of the avallability of protons, rather than of the hydrogen on concentration ${ }^{12}$ In modern biochemistry $\mathrm{pH}$ units are arbitrary and the $\mathrm{pH}$ of a test solution is related to the $\mathrm{pH}$ of a standard solution In the definition, the difference between the $\mathrm{pH}$ of the test solution and the $\mathrm{pH}$ of the standard solution is proportional to the difference in electromotive force produced across the glass electrode by the two solutions ${ }^{16}$

If this difference in $\mathbb{E} M$ is known, the $\mathrm{pH}$ value can be calculated theoretically using a certain mathematical formula which includes the absolute temperature It follows that the $\mathrm{pH}$ values measured by the $\mathrm{pH}$ meter change with temperature The $\mathrm{pH}$ of the buffer solutions used for the standardization also is temperature-dependent ${ }^{17}$ Thus when reporting $\mathrm{pH}$ values obtaned during hypothermia it is essential to state at which temperature the $\mathrm{pH}$ was measured

In the following paragraph the discussion will be restricted to an outline of acid base changes occurrng in patients under general anaesthesia with artificial resprration, cooled by blood stream coolng ${ }^{18}$ As a further simplification only two buffer systems (bicarbonate-carbonic acid and proteins) will be considered The pH can therefore be defined according to Henderson and Hasselbalch as follows

$$
\mathrm{pH}=\mathrm{pK}_{1}{ }^{\prime}+\log \left[\left(\mathrm{HCO}_{3}{ }^{-}\right) /\left(\mathrm{H}_{2} \mathrm{CO}_{3}\right)\right]=\mathrm{pK}_{2}{ }^{\prime}+\log \left(\mathrm{prot}^{-} / \mathrm{Hprot}\right)
$$

If two (or more) buffer parrs coexist in the same solution, they must be in equilibrium with the same hydrogen ion concentration $(\mathrm{pH})$ (isohydnc principle) $\mathrm{pR}^{\prime}$ is the symbol for the negative logarithm of $\mathbb{K}^{\prime}$, the apparent dissociation constant of the acid Each buffer system has its own $\mathrm{p} \mathbb{K}^{\prime}$, which under ord1nary circumstances remains constant It must be remembered, however, that the 
$\mathbb{K}^{\prime}$ is temperature-dependent and changes under hypothermia These changes have been studied by a number of investigators, and Severmghaus ${ }^{3}$ produced a nomogram for the calculation of the carbonic acid $\mathrm{p} K^{\prime}$ at varying temperatures

Rosenthal ${ }^{2}$ studied the effect of temperature on the blood $\mathrm{pH}$ He determined the $\mathrm{pH}$ of the same blood sample at varying temperatures and found a linear rise in $\mathrm{pH}$ during cooling The mean change was -00147 units $/{ }^{\circ} \mathrm{C}$ for blood, and this figure is widely quoted as "Rosenthal's correction factor" Many components of the acid-base balance are temperature-dependent, e $\mathrm{g}$ the dissociation constants, and the fact that according to physical laws more $\mathrm{CO}_{2}$ is dissolved in the plasma at a lower temperature than at normothermia The 1onization of all buffer anions is reduced at the lower temperature ${ }^{18}$ This leads to a decrease in the number of avalable hydrogen ions and thus to an increase in $\mathrm{pH}$. Evidently different processes influence the $\mathrm{pH}$ duing temperature changes and the net change in $\mathrm{pH}$ would be the sum of the different forces that may act synergist1cally or antagonistically

\section{(b) Physiological Considerations}

The results obtained by in vitio studies cannot be applied directly to the living organism under hypothermia Correction factors which have been determined by measurnng a certain variable anaerobically at different temperatures are applicable only under these conditions They are indispensable in the laboratory The blood sample is taken anaerobically at a low temperature and then warmed in the apparatus to body temperature before the measurement is made ${ }^{19}$

In a living animal under hypothermia the blood re-equilibrates Under anaerobic conditions the total $\mathrm{CO}_{2}$ content does not change, therefore cooling is assocrated with a decrease in $p \mathrm{CO}_{2}$ In the lungs (or in the oxygenator) the blood re-equilibrates with a similar alveolar carbon dioxide tension and accordingly, during the cooling, the $\mathrm{CO}_{2}$ content increases because of the increased solubility of $\mathrm{CO}_{2}$ It was first stressed by Brewin et al ${ }^{6}$ that conclusions based on in vitro experiments cannot be applied to the hypothermic animal

Conversely under hypothermia the same blood $\mathrm{CO}_{2}$ content is in equilibrium with a lower alveolar tension and consequently less $\mathrm{CO}_{2}$ will be excreted through the lungs However, in the tissues, less $\mathrm{CO}_{2}$ is being produced under these circumstances Other changes in the respiratory system, such as the increase in dead space at a lower temperature, ${ }^{7}$ also may influence the acid-base balance

The reasons for the acidosis which is commonly associated with hypothermia are not enturely clear Evidence has been presented that the hypothermic kidney cannot increase the excretion of hydrogen ions in the presence of acidosis ${ }^{21}$

In conclusion it can be stated that the effect of hypothermia on the acid-base balance is rather complex The ionization of all the buffer systems is decreased when the temperature is lowered and the effect of these changes is an increase in avallable bicarbonate Thus $\mathrm{pH}$ rises when the temperature falls On the other hand, more carbon dioxide is dissolved at the lower temperature and the increase in carbonic acid tends to counteract the $\mathrm{pH}$ shift to the alkalotic side ${ }^{22}$

The decreased 1omization of the other buffer pairs, together with an increase in the concentrations of bicarbonate and of carbonic acid under hypothermia, results 
in a relative preponderance of the latter buffer pair The total buffer capacity of the blood is thus reduced, the bicarbonate-carbonic acid system being comparatively inefficient in the physiological $\mathrm{pH}$ range with a $\mathrm{pK}^{\prime}$ of approximately 61 Accordingly, under hypothermia alterations in the $p \mathrm{CO}_{2}$ are relatively more effective in changing the $\mathrm{pH}$, and the small changes in $p \mathrm{CO}_{2}$ produce considerable $\mathrm{pH}$ shifts ${ }^{18}$

All the variables of the Henderson-Hasselbalch equation are temperaturedependent The determination of the acid-base balance in the laboratory at $37^{\circ}$ $\mathrm{C}$ thus presents a number of difficulties since correction factors and nomograms must be used which may not give precise results in a given patient The situation is further complicated by the observation that during the cooling process, there are temperature gradients between various parts of the body and even between various areas of the same organ ${ }^{18,23-26}$ Finally even if an exact assessment of the acid-base balance under hypothermia were possible its meaning would be doubtful since the optmal values for $\mathrm{pH}$ and blood gases at any given temperature are unknown 20

\section{Discussion of the Working Hypothesis}

Durnng extracorporeal circulation and hypothermia, an adequate blood supply to the vital organs usually can be maintained However, the artificial heart is not as efficient as the normal heart and maintenance of the cerebral circulation is a primary concern while the bypass is in progress Towards the end of the bypass the state of the myocardium assumes an importance equal to that of the brain since conditions must be created which are favourable for defibrillation and for the subsequent function of the heart These two aspects will now be discussed.

In adult men, the brain, the weight of which is approximately 2 per cent of the body werght, recerves 15 per cent of the cardiac output and consumes almost 20 per cent of the total oxygen requirement ${ }^{27}$ It is well known that the cerebral circulation is not governed by the same factors as the systemic and the pulmonary crrculation ${ }^{28}$ Provided the systemic blood pressure does not drop below a critical level of $60-70 \mathrm{~mm} \mathrm{Hg},{ }^{29}$ the cerebral crrculation is independent of the usual vasoconstricting and vasodilating effects ${ }^{30}$ The main factors influencing the cerebral circulation are the blood gas concentrations with a high $p \mathrm{CO}_{2}$ and a low $p \mathrm{O}_{2}$ producing cerebral vasodilatation and a low $p \mathrm{CO}_{2}$ and a high $p \mathrm{O}_{2}$ producing cerebral vasoconstriction ${ }^{31}$ It is not clear whether the high $p \mathrm{CO}_{2}$ causes the vasodilatation directly or whether the lowering of the $\mathrm{pH}$ is the responsible factor. Some investigators have presented evidence for the former, ${ }^{31,32}$ whereas others favor the latter theory ${ }^{33}$ Since this question is unsettled, it would appear to be preferable to induce both a high $p \mathrm{CO}_{2}$ and a low $\mathrm{pH}$ instead of a low $\mathrm{pH}$ only if a high cerebral blood flow is desired A similar vasodilating effect caused by carbon dioxıde and said to be independent of $\mathrm{pH}$ has been described in the systemic circulation ${ }^{34}$ and in the coronary circulation. ${ }^{35}$

Under the conditions of extracorporeal crrculation and bypass, a high oxygen tension is desirable It has been shown that this alone will not lead to an excessive decrease of cerebral blood flow ${ }^{36,37}$ To raise the $p \mathrm{CO}_{2}$ under these conditions may appear contrary to common practice since hyperventulation has been 
recommended during anaesthesia ${ }^{38}$ and especially during hypothermia ${ }^{39}$ The earler discussions centred manly around the prevention of ventricular fibrillation, which is one of the limiting factors of surface hypothermia It has been shown experimentally that a rapid fall from a high $p \mathrm{CO}_{2}$ level may produce ventricular fibrillation ${ }^{40}$ Others attributed the increased myocardial irritability to the acidosis produced by the high $\mathrm{pCO}_{2}{ }^{39,4142}$ Depression of the myocardial contractility was found to be associated with a low $\mathrm{pH}^{43}$ Accordingly, it has been recommended that increases in $p \mathrm{CO}$, be avoided altogether by hyperventlation during the period of hypothermia ${ }^{44}{ }^{45}$ This concept, however, has not been universally accepted ${ }^{46-49}$ Under conditions of hypothermia and hypocapnia the dissociation of oxygen from haemoglobin in the tissues may be impaired ${ }^{50}$ Hyperventilation also produces several changes in the blood chemistry in addition to a respiratory alkalosis ${ }^{51}$ In a discussion on the maintenance of the acid-base balance the increased excretion of sodium and potassium bicarbonate is of particular importance ${ }^{52}$ It has been well documented that acute respiratory alkalosis leads to a decrease in blood bicarbonate and to an increased bicarbonate excretion in the urine ${ }^{53,59}$ An increase in blood lactic acid has also been observed ${ }^{54}$

Conversely, in respiratory acidosis the renal tubular reabsorption of bicarbonate is increased, thus decreasing the bicarbonate excretion in the urine. A high $p \mathrm{CO}_{2}$ has been shown to be the main stimulus affecting the tubular feabsorption ${ }^{55}$ Conservation of base is of importance during any surgical operation, but especially under conditions of hypothermia since the hypothermic kidney is unable to produce an acid urme ${ }^{2156}$ It would seem, thes efore, that excessive hyperventilation before bypass should be avorded and that a moderate increase in $p \mathrm{CO}_{2}$ and a moderate decrease in $\mathrm{pH}$ durng bypass are of benefit since these changes cause a vasodilatation in the cerebral curculation

If hypothermia is produced by means of an extracorporeal circulation with an oxygenator in the circuit, the occurrence of ventricular fibrillation is of no significance At the low temperatures commonly used with this system and after cardiac arrest, the incidence of ventricular fibrillation is increased unless certain drugs are given ${ }^{57}$ The important thing, therefore, is not to prevent fibillation but to create conditions which are favourable for defibrillation at the end of bypass It has been suggested that defibrillation is accomplished most easily in the presence of an acidosis, ${ }^{58}$ although the evidence presented is rather meagre. Based on this same evidence, it has been the practice in certain centres to produce an acidosis by the intravenous administration of ammonium chloride, which later is neutralized with sodium bicarbonate Since the occurrence of a metabolic acidosis' is one of the major complications following hypothermia, ${ }^{6,58}$ this routine may not be without danger $\mathbb{A}$ respiratory acidosis can easily be corrected by subsequent hyperventulation and, while present, it actually preserves base ${ }^{60}$

The vasodilating effect of carbon dioxide has already been mentioned It appears to be particularly important under hypothermia when the viscosity of the blood is increased ${ }^{61}$ Further, the circulating blood volume has been reported to be increased during hypothermia ${ }^{6263}$ This may be due to pooling as a result of a loss in vasomotor tone ${ }^{64}$ although the total peripheral resistance has been reported to be increased under hypothermia ${ }^{85} \mathrm{~A}$ high blood flow and the pre- 
vention of a fall in blood pressure appear to be of special importance under hypothermia, since it has been reported that at lower temperatures the critical closing pressure in certain areas of the circulation may be higher than normal because of the increased viscosity ${ }^{66}$ If the blood pressure drops below the critical closing pressure this particular area would not be perfused at all The importance of maintaining a state of vasodilatation not only in the cerebral crrculation but also in the systemic circulation by preventing hypocapnia under these crrcumstances is evident

At this point, reference may be made to the experimental work on cooling to lower temperatures than those employed in this study, on freezing and supercooling Under these circumstances, as first shown by Giaja, the survival rate is increased if the animals are in a state of hypoxia and hypercapnia This work has been reviewed recently ${ }^{67}$ It appears that the effects of hypercapnıa are maintained at low temperatures Experimental evidence that curculatory reactions to a high $\mathrm{CO}_{2}$ are not abolished at $20^{\circ} \mathrm{C}$ has been presented ${ }^{18}$

During extracorporeal circulation when the gas exchange takes place in the oxygenator, the $p \mathrm{CO}_{2}$ can, within limits, be altered by the composition and the How rate of the gas to which the blood is exposed in the oxygenator The commonly used high flow rates of several litres of the gas mixture (approximately 975 per cent $\mathrm{O}_{2}$ and 25 per cent $\mathrm{CO}_{2}$ ) per minute provide an excess of oxygen It was found in preliminary studies that flow rates of one litre per minute and less provide adequate oxygenation of the artenal blood, this quantity of oxygen fully covering the oxygen requirements of the patient At these flow rates, the blood does not get nd of the $\mathrm{CO}_{2}$ and the $p \mathrm{CO}_{2}$ nses $\mathrm{A}$ high flow of the gas leads to a lowering of the $p \mathrm{CO}_{2}$ (a situation described by others ${ }^{69}$ ) but this type of "hyperventilation" is by no means as effective as the gas exchange in the lungs

Beiore the plan was finally adopted in patients, the literature was searched for evidence of possible side-effects of a temporary respiratory acidosis Although the problem is touched upon by several authors, no definite evidence of deleterious effects could be found $\mathrm{H}$ igh $\mathrm{CO}_{2}$ tensions were well tolerated by experimental animals $^{326068}$ and by patients ${ }^{70}$ Following hyperventilation with oxygen in normal subjects it was found that durnng breath holding the $p \mathrm{CO}_{2}$ may reach 90 $\mathrm{mm} \mathrm{Hg}{ }^{71}$ After the Astrup apparatus was set up, the acid-base balance of several patients was determined during open-heart surgery, using the perfusion methods which were in routine use at that time It was found that a change towards a higher $p \mathrm{CO}_{2}$ and a lower $\mathrm{pH}$ took place during normothermic and hypothermic bypass and that a comparatively small further increase in the $p \mathrm{CO}_{2}$ would lower the $\mathrm{pH}$ to the levels desired at the end of the cardiopulmonary bypass

The acid-base balance may be different in the various compartments of the body The measurement of the intracellular $\mathrm{pH}$ may produce new data which will help in the understanding of these problems Determination of the acid-base balance of the cerebrospinal flund may be of considerable importance since il may reflect certain metabolic aspects of the functions of the central nervous system Only few data are avallable ${ }^{72}$ It has recently been shown that little bicarbonate penetrates into the cerebrospinal fluid and that the $\mathrm{pH}$ is mainly determined by the $\mathrm{pCO}_{2}{ }^{72}$ These findings indicate that changes in the $\mathrm{pH}$ of the blood may not 
reflect $\mathrm{pH}$ changes in the cerebrospinal flud and that the administration of bicarbonate into the blood stream may not correct an acidosis in the cerebrospinal fluid The significance of this discrepancy, however, is unknown.

Hence it was postulated that during extracorporeal bypass, a $p \mathrm{CO}_{2}$ in the high normal range would be desirable It was further postulated that towards the end of a hypothermic bypass procedure a small further increase in $p \mathrm{CO}_{2}$ would provide a fall in $\mathrm{pH}$ which would facilitate defibrillation An adequate monitoring technique for the control of the acid-base balance was avallable Whereas the value of the addition of $\mathrm{CO}_{2}$ to the gas mixture had been recognized before, it is only since the introduction of a satisfactory monitoring technique that a deliberate attempt at increasing the carbon dioxide tension of the patient has been undertaken. Carbon dioxide has also been used to lower the $\mathrm{pH}$ to the desired level by a group using the Edmark technique, i e deliberately lowering the $\mathrm{pH}$ as the temperature falls ${ }^{74}$

Although primarily designed for use in patients under hypothermia, the concept was thought also to be of value for bypass procedures done at normal temperature General and cerebral vasodilatation again is important but the additional acidosis at the end of the bypass is not necessary since ventricular fibrillation ordınarily does not occur Accordingly, an attempt was made to raise the $p \mathrm{CO}_{2}$ to the normal range durng bypass but not higher The other phases of the operation were handled as described for the hypothermic cases

\section{Discussion of Results}

In this clinical study the temperature of the Astrup apparatus could not be altered since the equipment had to be avallable at the same tume for the routine laboratory work of the hospital Further, under conditions of farly rapidly induced hypothermia there are considerable temperature gradients between various parts of the body and the body temperature as such cannot be defined For these reasons all the determinations were done at a temperature of $37^{\circ} \mathrm{C}$ and correction factors were apphed The values were corrected to the temperature of the blood in the oxygenator This temperature is close to the temperature of the mixed venous blood of the patient since the heat exchanger was incorporated in the arterial line

The correction factor $-00147 /{ }^{\circ} \mathrm{C}$ described by Rosenthal ${ }^{2}$ is similar to the ones reported by others ${ }^{75-77}$ Considering the old definition of the $\mathrm{pH}$ as an expression of the hydrogen ion concentration, a similar factor can be calculated taking into account the increase in the dissociation constant of water with an increase in temperature and disregarding all other changes At $25^{\circ} \mathrm{C}$ a $\mathrm{pH}$ of 7 signifies neutral reactions, according to the old formula

$$
\left(\mathrm{H}^{+}\right)=\left(\mathrm{OH}^{-}\right)=10^{-\tau}
$$

With increasing temperature the dissociation constant of water incieases and at $37^{\circ} \mathrm{C}$ a neutral reaction is indicated by a $\mathrm{pH}$ of 681 Accordingly, the $\mathrm{pH}$ drops $019 / 12=00158$ per degree temperature rise ${ }^{78}$

When the patient's blood was warmed to $37^{\circ} \mathrm{C}$, before the $p \mathrm{CO}_{2}$ was determined, erroneously high results were obtained and these were corrected using the nomogram of Severinghaus ${ }^{3}$ 
With regard to base excess or to deficit, data on temperature changes have not been found in the literature Small changes may take place and this problem needs further investigation In this work the uncorrected values obtanned with Astrup's method were reported

There are two major difficulties in assessing the possible benefits of the method In this senes all the hearts which fibrillated (except one) could be defibrillated with one electrical shock But it is a clinical series without controls and it is impossible to state definitely that the low $\mathrm{pH}$ really did facilitate the defibrillation It is equally difficult to assess the cerebral circulation quantitatively with the evidence avallable Unfortunately the electroencephalogram was recorded on an oscilloscope, and no permanent records have been kept in the majority of cases It is our impression that at $25^{\circ} \mathrm{C}$ body temperature, the E E G shows more fast wave activity and a higher amplitude when the $p \mathrm{CO}_{2}$ is deliberately increased

The other dufficulty of assessment stems from the fact that the method was introduced gradually As outlined previously, a mixture of $\mathrm{O}_{2}$ and $\mathrm{CO}_{2}$ was used in all our pump cases After the introduction of an adequate monitorng system, it was found that a certain degree of $\mathrm{CO}_{2}$ retention took place durng extracorporeal bypass with and without hypothermia Based on the theoretıcal considerations mentioned above, the $\mathrm{CO}_{2}$ retention was then deliberately increased This was done gradually, trying to obtain higher and higher $p \mathrm{CO}_{2}$ 's as time went on Consequently there is no sharp dividing line between two groups which could be compared by means of the conventional statistical methods

The mean values obtained in the patients' arterial blood before bypass, towards the end of the bypass, and at the end of the operation are given in Table II In seven adult patients the first arterial blood sample could be taken before anaesthesia The samples labelled "after anaesthesia" were taken 30-60 minutes after the start of the anaesthesia The samples labelled "before bypass" were taken from the patient either through an arterial needle in the radial artery or from the aorta By that time the patient had been under anaesthesia for two hours or longer The effects of moderate hyperventilation are readily apparent The progressive base defict has been observed by others under similar circumstances 79,80 In order to assess the base deficit, the same figure obtained in an arterial blood sample taken before the patient is given the preanaesthetic medication should be avalable for comparison However, in the patent's interest it was decided not to take this sample, which would have necessitated an arterial puncture at $630 \mathrm{am}$ on the day of surgery The zero value used by Astrup ${ }^{8}$ corresponds to a standard bicarbonate concentration of $229 \mathrm{mEq} / \mathrm{L}$ in the serum It cannot be assumed that all our patients started out with this concentration, although the means and standard deviations indicate that some were in the zero range at the beginning of anaesthesia and also after one to two hours of anaesthesia

Durning bypass blood samples were taken every $10-20$ munues at the artenal end of the oxygenator For the purpose of comparison the data obtained in the sample with the lowest $\mathrm{pH}$ for each run were analysed further and the means are reported in the table Since a progressive acidosis developed while the bypass was in piogress, this usually was the last sample taken during bypass In the patients whose temperature dropped at least two degrees, correction factors were applied, 
and the means of both corrected and uncorrected values are reported The mean corrected $\mathrm{pH}$ values were 732 in the normothermia group and 733 in the hypothermia group values which are considered to be slightly acidotic The $p \mathrm{CO}_{2}$ values (corrected for temperature when necessary) were found to be near the normal range during the bypass, but the means do not give the correct picture A gradual increase of $p \mathrm{CO}_{2}$ values to the normal range and slightly higher than normal occurred during bypass Durng short runs, the normal range was not reached, hence the values obtamed towards the end of bypass in the short cases as a rule were below the mean, whereas those obtained in longer cases were above the mean

Occasionally a rapid increase of the $p \mathrm{CO}_{2}$ was observed as soon as the cardiopulmonary bypass was started This may be due to the fact that the $p \mathrm{CO}_{2}$ of the blood increased as its temperature increased If blood is warmed from $25^{\circ} \mathrm{C}$ to body temperature the $p \mathrm{CO}_{2}$ almost doubles and $\mathrm{CO}_{2}$ may be given off to the body under these circumstances ${ }^{81}$ In accordance with this theory the practice was adopted in hypothermia cases of exposing the blood in the oxygenator to air instead of the $\mathrm{O}_{2}-\mathrm{CO}_{2}$ mixture Another reason for this practice is the possibility of oxygen bubble formation if the cold blood is exposed to a high oxygen concentration ${ }^{82}$

The increase in base deficit during bypass was not unexpected Large quantities of bank blood had been added to the patients' blood Although a large transfusion is well tolerated by a patient in the absence of shock, ${ }^{80}$ during bypass this may account for part of the acidosis Furthermore, in the course of prolonged procedures, a base deficit develops even when high perfusion flows are used ${ }^{83}$ and in the two cases with circulatory arrest it was anticipated that a deficit would occur ${ }^{84}$ although other investigators have not confirmed this finding ${ }^{69}$ Under no curcumstances was the base deficit allowed to drop below $10 \mathrm{mEq} / \mathrm{L}$ When that arbitrary limit was reached, sodium bicarbonate was given intravenously ( 3 patients)

At the end of the operation the $\mathrm{pH}$ had nsen to low normal values The $p \mathrm{CO}_{2}$ had fallen slightly and there was still a base deficit although less than at the end of the bypass The deficit was slightly less pronounced in patients who were operated upon under normothermia than in those who were cooled The small difference may be accounted for by the fact that the hypothermia group comprises the more difficult cases with longer bypass penods On the other hand, the possibility that a metabolic acidosis always occurs following hypothermia cannot be discounted ${ }^{18} 59$ The causes of this tendency towards acidosis are not readily apparent It was conceivable that under hypothermia the avallability of oxygen to the cells decreases more than the oxygen requirements of the cells, resulting in a relative hypoxia There is some experimental evidence that this may be the case ${ }^{85}$

The increase in base deficit during the first penod of the procedure, before the bypass was started, was found to be similar in magnitude to the further increase which occurred during and following bypass. This second period was considerably longer than the first one and furthermore, durng the second penod, large amounts of the more acidotic blood were given as priming volume of the pump oxygenator and as transfusion The further increase in acidosis may indicate, however, that the perfusion was not as efficient as the normal blood circulation, 
resulting in inadequate tissue perfusion which in time may cause anaerobic metabolism and acidosis ${ }^{80}$ Following bypass, the compensatory mechanisms decreased the base deficit again and no patients received additional base during this period.

In order to produce an acidosis at the end of the cardiopulmonary bypass, as postulated in the working hypothesis, it was not necessary to give intravenous ammonium chlonde $\mathrm{A}$ base deficit (or excess acid) was already present If the $\mathrm{pCO}_{2}$ was increased from the low levels found before bypass to the normal range or somewhat higher, the $\mathrm{pH}$ dropped to the desired level Following bypass the $p \mathrm{CO}_{2}$ was lowered again by controlled respiration and the base deficit was partly corrected by the body's regulatory mechanisms. Thus at the end of the operation the acid-base balance was close to the normal range. By paying meticulous attention to the acid-base balance throughout the whole procedure this was usually achieved without additional infusion of sodium bicarbonate

Over-breathing may occur with controlled respiration under anaesthesia and a progressive loss of base may follow. Indeed, it has been shown that the acidosis associated with thoracic operations for a variety of reasons is similar to that observed following open-heart surgery ${ }^{79,86}$ The results obtaned in this study confirm this finding since they suggest that a part of the acid shift occurred before the bypass was started The production of a respiratory alkalosis is common anaesthetic practice ${ }^{38}$ In this series vigorous hyperventilation was avoided and the results show that the respiratory alkalosis was of a mild degree After completion of the extracorporeal circulation hyperventulation was employed in order to increase the carbon dioxide excretion but no attempt was made to induce a respiratory alkalosis Again vigorous hyperventilation was avoıded as before bypass

The $\mathrm{pH}$ thus underwent a cyclical change After an initial rise during bypass there was a progressive fall in $\mathrm{pH}$ associated with a return of the $p \mathrm{CO}_{2}$ to normal levels or slightly higher After termination of the bypass the $p \mathrm{CO}_{2}$ was reduced by controlled respiration At the end of the operation the $\mathrm{pH}$ returned to a normal level in the majonty of the patients In some cases a slight metabolic acidosis persisted at that tume, which always was corrected spontaneously without further treatment This would appear to be a physiological way to handle the acid-base balance during extracorporeal circulation and hypothermia avoiding the addition of acidifying substances and avoiding the administration of base unless it is specifically required

At every stage of the procedure large shifts of the $\mathrm{p} \mathbb{H}$ in etther direction were avolded The importance of preventing extensive changes in $\mathrm{pH}$ has been outlined by several investigators ${ }^{87} 88$ It is interesting to note that the prevention of an excessively low $\mathrm{pH}$ during extracorporeal circulation and hypothermia was one of the main arguments of those who recommend hyperventilation and/or the use of pure oxygen in the oxygenator ${ }^{89}$ It is questionable, however, whether all authors included the necessary correction factors in the calculation of the actual $\mathrm{pH}$ of the patients Furthermore, according to the working hypothesis, a temporary lowering of the $\mathrm{pH}$ at the end of the bypass was thought to be desirable and no attempt was made to prevent the fall, in fact, it was deliberately induced In addition to facilitatung ventricular defibrillation and the other effects outlined in the discussion, the high $\mathrm{CO}_{2}$ conserves base by diminishing the renal excretion 
of bicarbonate and in so doing it may help prevent a metabolic acidosis in the recovery penod By carefully monitoning both the respiratory and the metabolic acid-base balance ${ }^{90}$ and by adopting the management described, the patients can have the benefits of a high $\mathrm{CO}_{2}$ dunng long perfusions and those combined with hypothermia, without being exposed to the risks of excessive changes in the blood $\mathrm{pH}$ The principles of the method, therefore, are close to those outlined recently by Theye et al,${ }^{91} \mathrm{eg}$ "munmal interference with and maximal preservation of" the various body functions

It should be remembered, however, that the whole concept is based on a number of assumptions, some of which may not be found acceptable in the future The problems associated with the measurement of $\mathrm{pH}, p \mathrm{CO}_{2}$, and bicarbonate at low temperatures are being actively investigated in many centres and it is quite possible that some of our ideas will change

\section{Summary ANd Conclusions}

Many aspects of the acid-base balance during extracorporeal curculation and durnng hypothermia are still problematic In this paper the theoretical background is reviewed which led to the adoption of the following working hypothesis

The acid-base balance has a direct influence on two important aspects of cardiopulmonary bypass During bypass a high carbon dioxide tension will ensure an adequate cerebral blood flow and at the end of the bypass a low $\mathrm{pH}$ is sand to facilitate defibrillation Both these conditions can be created by avoiding excessive hyperventilation of the patient before bypass and by increasing the $p \mathrm{CO}_{2}$ durng bypass The arterial $p \mathrm{CO}_{2}$ was controlled by varying the volume of the $\mathrm{O}_{2} / \mathrm{CO}_{2}$ gas mixture dellvered to the oxygenator

The method has been employed in 72 consecutive patients The acid-base balance was monitored using Astrup's apparatus Large $\mathrm{pH}$ shifts were avorded and clinically the patients appeared to do well under this type of management

The rationale of the concept is discussed and it is concluded that it has been of benefit for the patients upon whom it was/used

\section{RÉSUMÉ}

Plusieurs aspects de l'équilibre acide-base au cours de la crrculation extracorporelle et de l'hypothermie demeurent encore problématıques Dans cet artıcle, nous revoyons la théone de base qui conduit à l'adoption de l'hypothèse suvvante

L'équilibre acide-base exerce une influence directe sur deux aspects importants de la circulation cardio-pulmonarre extracorporelle $\mathrm{Au}$ cours de la circulation extracorporelle, un taux élevé de gaz carbonıque va assurer un débıt sangun cérébral adéquat et, à la fin de la circulation, un $\mathrm{pH}$ bas est supposé facilter la défibrillation Ces deux états peuvent être réalısés en évitant une hyperventılation excessive du malade avant la crrculation extracorporelle et en augmentant la pression de $\mathrm{CO}_{2}$ au cours de cette circulation $\mathrm{La} p \mathrm{CO}_{2}$ arténelle a été maintenue en variant le volume du mélange gazeux $\mathrm{O}_{2} / \mathrm{CO}_{2}$ introdut dans l'oxygénateur 
Nous avons utlisé cette méthode chez 72 malades consécutıfs La courbe de l'équilıbre acıde-base a été visualısée grâce à l'appareil Astrup Nous avons évité des changements marqués du $\mathrm{pH}$ et, clınıquement, bette façon de procéder a semblé avantageuse à nos malades Nous avons exposé la logique de ce point de vue, et nous en venons à la conclusion que, chez le, malades où nous l'avons utıllsée, cette méthode a rendu service

\section{ACKNOWLEDGMENTS}

The author is indebted to the members of, the cardiac surgery teams of the Winnipeg Children's Hospital and of the Winnipeg General Hospital for their ee-operation in obtaining the data presented in this paper, and in particular to $D_{1}$ Colin C Ferguson, Professor and Head of the Department of Surgery and to Di H D Sanders, Department of Pharmacology and Therapeutics, for their help in the preparation of this manuscript

\section{REFERENCES}

I Siggaard Anderson, O, Engel, K, Torgensen, $K$, \& Ait Trup, $\mathbb{P}$ A Micromethod for Determination of $\mathrm{pH}$, Carbon Dioxide Tension, Base Excess and Standard Bicarbonate in Capillary Blood Scand J Clin Lab Investigation, 12 172 (1960)

2 Rosenthal, T B The Effect of Temperature on the pH of Blood and Plasma in Vitro J Biol Chem 17325 (1948)

3 Severinghaus, J W, Stupfel, M, \& Bradley, A F Variation' of Serum Carbonic Acid $\mathrm{pK}^{\prime}$ with $\mathrm{pH}$ and Temperature J Appl Physiol 9197 (1956)

4 Bigelow, W G Methods for Inducing Hypothermia and Rewarming Ann N Y Acad Sc1 $80 \quad 522$ (1959)

5 Nunv, J F Nomenclature and Presentation of Hydrogen Ion Regulation Data In Modern Trends in Anaesthesia, Vol 2, edited by $F$ T Evans and $T$ C Gray London Butterworths (1962)

6 BrewiN, E G, Gould, R P, NASHat, F S, \& NeIr, E An Investigation of Problems of Acid-Base Equilibrium in Hypothermia Guy's IHosp Rep 104177 (1955)

7 Siggaard Anderson, O A Graphic Representation of Changes of the Acid-Base Status Scand J Clin Lab Investgation 12311 (1960)

8 Astrup, $\mathbb{P}$, Torgensen, $\mathrm{K}$, Siggard Anderson, O, \& Enjer, $\mathrm{K}$ The Acid-Base Metabolism A New Approach Lancet 11035 (1960)

9 SiggaArd Anderson, $O$ \& Engel, $K$ A New Acid-Base Nomogram Scand J Chn Lab Investigation 12177 (1960)

10 CREewe, $R$, NeIL, M W, Ledingriam, J M, \& Vere, D W The Terminology of AcidBase Regulation Lancet 2419 (1962) and subsequent letters to the Editor

11 NeIr, $\mathrm{E}$ In A Symposium on $\mathrm{pH}$ and Blood Gas Measurement, edited by $\mathrm{R} F$ Woolmer London Churchill (1959)

12 Clark, $\mathbb{W}$ Topics in Physical Chemistry, 239 Baltımoie Williams and Wilkins (1948)

13 Edsali, J T and Wyman, J Biophysical Chemistry, Vol L, p 406 New York Academic Press (1958)

14 WillafD, H H, MERitt, $L$ L, \& DEAN, I A Instrumental Methods of Analysis Pnnceton Van Nostrand (1958)

15 Hitchcock, D L Physical Chemistry of Blood In T C Ruch and J F Fulton, Medical Physiology and Biophysics Philadelphia W B Saunders (1960)

16 Woolmer, $\mathrm{R}$ The Measurement of $\mathrm{pH}$ and $\rho \mathrm{CO}_{2}$ In Modern Trends in Anaesthesia, Vol 2, edited by F T Evans and T C Gray London Butterworths (1962)

17 MatтocK, G Electrochemical Aspects of Blood $\mathrm{pH}$ Measurements In A Symposium of pH and Blood Gas Measurement, edted by $\mathbb{R} \mathbb{F}$ Woolmer London Churchill (1959)

18 Cooper, $\mathbb{K}$ E \& Ross, D N Hypothermia in Surgical Practice London Cassell (1960)

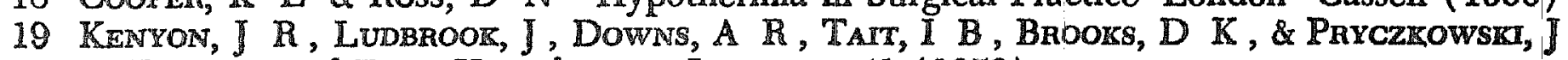
Expermental Deep Hypotherma Lancet is 41 (1959) 
20 Severinghaus, J W Respiration and Hypothermia Ann N Y Acad Sci 80384 (1959)

21 Kanton, G S Unne Titratable Acidity and Ammonia Excretion dunng Hypothermia Technical Documentary Report No SAM-TOR-63-8, USAF School of Aerospace Med1cine, Aerospace Medical Division (AFSC), lBrook, Air force Base, Texas (1963)

22 Cranston, W I , Pepper, M C, \& Ross, D N Carbon Dioxide and Control of Respiration during Hypothermia J Physiol 127380 (1955)

23 Cooper, $\mathrm{K}$ E \& Kenyon, $J$ R A Comparisor of Temperatures Measured in the Rectum Oesophagus and on the Surface of the Aorta during Hypothermia in Man Bnt J Surg 44616 (1957)

24 BoвA, A Hypothermia for the Neurosurgical Patient Springfield C C Thomas (1960)

25 Severinghaus, J W Temperature Gradients during Hypothermia Ann N Y Acad Sci. 80515 (1959)

26 ZingG, W, McGoey, J S , \& Kantor, S Observations on the Temperature of the Brain durng Induced Hypothermia in Dogs Can J. Surg 5340 (1962)

27 Mcllwain, H Biochemistry and the Central Nervous System Toronto Little (1959)

28 KETY, S S Circulation and Metabolism of Hiuman. Brain in Health and Disease Am J Med 8205 (1950)

29 Sozoloff, L \& KeTY, S S Regulation of the Cerebral Circulation Physiol Rev 4038 (1960)

30 Carlyle, A \& Grayson, J Factors Involved in the Control of Cerebral Blood Flow J Physiol 13310 (1956)

31 Patterson, J L Circulation through the Bran In $\mathrm{T} C$ Ruch and J $\mathrm{F}$ Fulton, Medical Physıology and Biophysics Philadelphia W B Scunders (1960)

32 Pierce, E C Cerebral Circulation and Melabolsm durmg Thiopental Anesthesia and Hyperventulation in Man J Clin Inves 41 1664 (1962)

33 Kety, S S, Polts, D E, Nadlen, C S, \& Schmm r, C F The Blood Flow and Oxygen Consumption of the Human Brain in Diabelic Acidosis and Coma J Clin Investigation 27500 (1948)

34 Page, J H \& Oldistead, F The Influence of Respiratory Gas Mixtures on Artenal Pressure and Vascular Reactivity in "Nonnal" and Hypersensitive Dogs Circulation 3801 (1951)

35 Barach, A L \& Steiner, A The Physiologic Action of Oxygen and Carbon Dioxide on the Coronary Circulation, as Shown by Blood Gas and Electrocardıographic Studies Am Heart J 2213 (1941)

36 Kety, $\mathrm{S} S$ \& Schmid, $\mathrm{C} F$ Effects of Altered Artenal Tensions of $\mathrm{CO}_{2}$ and $\mathrm{O}_{2}$ on Cerebral Blood Flow and Cerebral Oxygen Consumption J Chn Investigation 27484 (1948)

37 Woolff, H G \& Lennox, W G The Cerebrall Circulation XII The Effect on Pial Vessels of Varnations in the Oxygen and $\mathrm{CO}_{2}$ Content of the Blood Arch Neurol Psychiat 231097 (1930)

38 Robinson, J S Hyperventilation In Modern Trends in Anaesthesia, Vol 2, eduted by F T Evans and T C Gray London Butterworths (1962)

39 Swan, H, Zeavin, I, Holmes, J H, \& Montgomery, V Cessation of Circulation un General Hypothermia Ann Surg 138360 ( 1953)

40 Brown, E B \& Miller, F Ventricular Fibrillation Following a Rapid Fall in Alveolar Carbon Dioxide Concentrations Am J Physiol 16956 (1952)

41 Campbell, G S Cardiac Arrest Further Studies on the Effect of pH Changes on Vagal Inhibition of the Heart Surgery 38615 (1955)

42 Fleming, $R$ Acid-Base Balance of the Blood in Dogs at Reduced Body Temperature Arch Surg 68 145 (1954)

43 Price, H L \& Helrich, M The Effect of Cyclopropane, Diethyl Ether, Nitrous Oxide, Thropental, and Hydrogen Ion Concentration on the Myocardial Function of the Dog Heart-Lung Preparation J Pharmacol \& Exper Therap 115206 (1955)

44 Virtue, R W Hypothermic Anesthesia. Springfield C C Thomas (1955)

45 Detrerling, R A, Nelson, E, Bhonslay, S, \& Howland, W Study of Basic Physiologic Changes Associated with Hypothermia. Arch Surg 7085 (1955)

46 Lewis, F J \& Niazi, S A The Use of Carbon Dioxade to Prevent Ventricular Fibrillation durng Intracardiac Surgery under Hypothermia Surg For 6134 (1955)

47 Niazi, S A \& LewIS, F J Profound Hypotherma in the Dog Surg, Gynec Obst 102 $98(1956)$

48 Lewis, F J \& Niazi, S A A Technique Employng Hypothermia for the Repair of Atrial Septal Defects Surg, Gynec \& Obst 106751 (1958) 
49 Moulder, P V, Thompson, R G, Smith, C A, Sieger, B L, \& Adams, W E Cardiac Surgery with Hypothermia and Acetylcholine Arrest J Thoracic Surg 32360 (1956)

50 Carryer, H M Tissue Anoxia Resultung from Respiratory Alkalosis Proc Staff Meet Mayo Clin 22456 (1947)

51 Henneman, D H, Bunker, J $\mathbb{P}$, \& Brewster, W $\mathbb{R}$ Immedlate Metabolic Response to Hypothermia in Man J Appl Physiol 12164 (1958)

52 Stanbury, S W \& Thompson, A E The Renal Response to Respiratory Alkalosis Chn Sc1 11357 (1952)

53 Barker, E S, Singer, R B, Elzington, J R, \& Crafu, J $K$ The Renal Response to Acute Experimental Respiratory Alkalosis and Acidosis J Clin Investigation $36 \quad 515$ (1957)

54 Anderson, $\mathrm{M}$ N \& Svane, $\mathrm{H}$ Pattem of Biochemical Response to Acute Change in $p \mathrm{CO}_{2}$ Ann Surg 156752 (1962)

55 Dorman, P J, Sullivan, N J, \& Pitts, R F The Renal Response to Acute Respiratory Acidosis J Clin Investigation 3382 (1954)

56 KanteR, G S Bicarbonate Excretion during Hypothermia Can J Biochem Physiol 41 $91(1963)$

57 Gollan, F Physiology of Deep Hypotherma by Total Body Perfusion Ann N Y Acad $\mathrm{Sc1} 80301$ (1959)

58 Edmark, $\mathrm{K}$ W Contnuous Blood $\mathrm{pH}$ Measurement with Extracorporeal Cooling Surg, Gynec \& Obst 109743 (1959)

59 Axerrod, D R \& Bass, D E Electrolytes and Acid-Base Balance in Hypothermia Am J Physiol 18631 (1956)

60 Nunn, J F The Effects of Hypercapnia In Modern Trends in Anaesthesia, Vol 2, edited by $\mathrm{F} T$ Evans and T C Gray London Butterworths (1963)

61 BonHOEFFER, $\mathrm{K}$ \& EIGLER, $\mathrm{F}$ W Bestimmung der Viscositat von Runderblut fur Haematokntwerte von $0-90 \%$ bet Temperaturen von $3-38^{\circ}$ Plluegers Arch 273579 (1961)

62 Hodgson, D C \& Parkhouse, J Management of Anaesthesia during Profound Hypothermia Bnt J Anaesth 33303 (1961)

63 YEH, T J, ELLison, L T, \& Ellison, R G Hemodynamic and Metabolic Responses of the Whole Body and Individual Organs to Cardiopulmonary Bypass with Profound Hypothermia J Thoracic Cardıovase Surg 42782 (1961)

64 Oz, M, Hameya, S, Nevilus, W, \& Clowes, G H A Relationship of Blood Volume, Systemic Peripheral Resistance and Flow Rate durng Profound Hypothermia Trans Am Soc Artif Int Organs 6 204 (1960)

65 King, H \& Bounous, G Cardiac Input in Hypothermia Surg, Gynec \& Obst 107753 (1958)

68 Bonhoeffer, H, Eigler, F W, GeHL, H, \& PeIPefl, H J Experimentelle Untersuchungen zum Verhalten des gesamten Kreslaufwiderstandes bel tefer Hypothermue in extrakorporaler Zirkulation Dtsch Ztschr Chir $298 \quad 824$ (1961)

67 Sмith, A U Biological Effects of Freezing and Supercooling London Edward Amold (1961)

68 Brendel, W, Albers, C, \& Usinger, W Die Reaktıvitat des Kreislaufs in Hypothermie Pfluegers Arch $266 \quad 357$ ( 1958 )

69 Stephen, C R, Dent, S J, Hall, K D \& Smith, W W Physiologic Reactions dunng Profound Hypothermia with Cardioplegid Anesthesiology 22873 (1961)

70 Clowes, G H A, Hoprins, A L, \& Simeone, F A A Companison of Physiological Effects of Hypercapnia and Hypoxia in the Production of Cardiac Arrest Ann Surg 142446 (1955)

71 KLOCKE, F J \& RAHN, H Breath Holding after Breathing Oxygen J Appl Physiol 5 689 (1959)

72 Merril, $\mathrm{C} \mathbb{R}, \mathrm{Semp}, \mathbb{H} \mathrm{W}$, \& Luchsinger, $\mathbb{P} \mathrm{C}$ Total $\mathrm{CO}_{2}, p \mathrm{CO}_{2}$ and $\mathrm{pH}$ in Hurman Spinal Fludd J Appl Physiol 16485 (1961)

73 Cowie, J, LAMmie, A $T$, \& RoBson, J S The Influence of Extracorporeal Dialysis on the Acid-Base Composition of Blood and Cerebrospinal Fluid Cln Sci 23397 (1962)

74 Carson, S A A \& Morrus, L E Contiolled Acid-Base Status with Cardiopulmonary Bypass and Hypotherma Anesthesiology 23618 (1962)

75 Craig, F A, Lange, $\mathbb{K}$, Oberman, $J$, \& Carson, $S$ A Simple Accurate Method of Blood pHI Determmations for Clinncal Use Arch Biochem Brophys 38357 (1952)

76 Din, D B, Fonbes, W H. \& DALY, C The pK' of Serum and Red Cells J Biol Chem $117569(1937)$ 
77 Dill, D B \& Fories, W $\mathbb{H}$ Respiratory and Metabolic Effects of Hypothermia Am J Physiol 132685 (1941)

78 Winterstein, H Der Einfluss der Korpertemperatur auf das Saeure-Basen-Gleichgewicht im Blut Arch exper Pathol Pharmakol 223 1 (1954)

79 Dobell, A R C, Gutelius, I R, \& MuhPhy, D $\mathbb{R}$ Acidosis Following Respiratory Alkalosis in Thoracic Operations with and without Heart-Lung Bypass J Thor Cardiovasc Surg 39312 (1960)

80 Schweizer, $O$ \& Howland, W S Disturban'es in Acid-Base Balance durnng Major Surgery Anesthesiology $24 \quad 158$ (1963)

81 Marshall, $R$ \& Gunning, A The Measurement of Blood Gas Tensions durng Profound Hypothermia J Surg Res 2351 (1962).

82 Donald, $\mathrm{D}$ E \& Feliows, J L Physical Factors Relating to Gas Embolism in Blood J Thor Cardiovase Surg 42110 (1961)

83 Jonss, $R$ S The Acid-Base Changes due to Cardiac Bypass In Modern Trends in Anaesthesia, Vol 2, edited by $\mathrm{F} T$ Evans and $\mathrm{T} C$ Gray London Butterworths (1962)

84 Bernitard, W F, Carroll, S E, Schwarz, $\mathbb{H}$, \& Gross, $\mathbb{R}$ E Metabolic Alterations Associated with Profound Hypothermia and Extracorporeal Circulation in the Dog and Man J Thor Cardiovasc Surg 42793 (1961)

85 Beaton, $J \mathbb{R}$ Further Observations on Metabolic Alterations in the Hypothermic Rat Can J Brochem Physiol 39 1 (1961)

86 Eliot, E C \& Callaghan, J C Acid-Base Changes in Dogs with and without Extracorporeal Crrculation Can J Surg 2185 (1959)

87 OsBonN, J J Experimental Hypothermia Respuatory and Blood $\mathrm{pH}$ Changes in Relation to Cardiac Function Am J Physiol 175389 (1953)

88 WadDELL, W J, FAIRLAy, H B \& Bigezow, W G Improved Management of Clinical Hypotherma Based upon Related Biochemical Studies Ann Surg 146 542 (1957)

89 Drew, C E Profound Hypotherma in Cardiac Surgery Brat Med Bull 17. 37 (1961)

90 ZINGg, W The Monitoring of the Acid-Base Status dunng Cardiopulmonary Bypass with Astrup's Method Trans Am Soc Artufic Int Organs 8 64 (1962)

91 Theye, $\mathbb{R}$ A, Moffit , $\mathbb{E}$ A, \& Kirkuin, J W/ Anesthetic Management dunng Open Intracardiac Surgery Anesthesiology 23823 (1962) 